\title{
Geriefsvoedsels: beroepsvroue se persepsies
}

\author{
Martha Kok, Priscilla Botha \& Annemarie Therese Viljoen
}

\begin{abstract}
SUMMARY
The purpose of the study was to understand and describe career women's perceptions of the product characteristics of convenience food. It is often assumed that career women should be a target market for convenience food because they have money, and experience time and role constraints. Perceptions are formed as a result of the interpretation of sensory stimuli (taste, smell, texture, vision and hearing) and storage thereof in the memory schemata. Consumers' perceptions of product attributes therefore serve as frame of reference for the choice, purchase and use of convenience foods and can be of value to the food industry. Convenience food is defined as any fully or partially prepared dish, food product or ingredient (s) in which significant preparation time and/or culinary skills, and/or energy inputs have been transferred from the homemaker's kitchen to the food industry.
\end{abstract}

A cognitive theoretical approach and a grounded theory approach (a qualitative methodology) were used in the study. Eight career women were chosen as participants who met the criteria for inclusion, eg a professional career and a workweek of at least 40 hours/week. Participants from two age categories were included. They were single or married, as well as with or without children. Hereby the differences between cases were maximised and minimized. Basic individual interviewing and a projective technique were used to gather qualitative data. Cash slips, field notes and observations in the supermarket were used as additional sources of data and for triangulation purposes. Data analysis included open, axial and selective coding.

The most salient findings were:

Career women have both positive and negative perceptions about the attributes of convenience food. The attributes mentioned were price, taste, convenience, appearance, health, safety and quality. These attributes are interrelated and influence one another. The price of a convenience product is influenced by the number of portions, taste, convenience, the appearance of the product as well as the ambiance of the retail environment. Single career women seem to be more willing to purchase convenience products than those with families because of the cost involved in buying individual ingredients as opposed to a single product. Taste, the most salient attribute, is influenced by the perception of the taste of the home-made equivalent or what they are used to. Positive perceptions were attributed to products of which the taste could be adjusted to own preferences and where product ranges allow for choice between flavour variants. Negative perceptions were attributed to taste if the texture did not conform to the expectations of the individual. Convenience is experienced when products save time, physical and cognitive effort and energy when buying and preparing the food. Appearance was related to the colour and the neatness of vegetable cuts in particular, the packaging of the product and also the store appearance. Participants were very aware of the fat content of convenience products, especially during the week. Fat content of foods are related to body mass and health. During weekends, however, it seemed as if they were more relaxed in their attitude towards fat. The safety of convenience food was not uppermost in the memory schemata of these participants and it can possibly be explained by the fact that they are educated and able to distinguish between safe and unsafe food products. Some participants were cautious of fully prepared, ready-to-eat food products due to the fact that they were uncertain of the turnover as well as the temperature control of these foods in store. Although quality perceptions differ for different people, the above-mentioned attributes can all be linked to quality, because products bought represent the required quality by the participants.

Risk perception seems to result from negative perceptions of taste and price and may lead to avoidance of convenience food products. Some participants had risk perception regarding the microbiologic safety of certain fully prepared convenience foods.

Retail outlets (eg supermarkets) also seem to guide perceptions of participants regarding convenience foods. The ambiance of the retail outlet and the participants' familiarity with and trust in the outlet are all aspects that may influence their perceptions regarding the store and its products.

Understanding of participants' perceptions of the attributes of convenience foods could shape future product development or could be used to improve slow moving product lines. A multi-disciplinary approach among food scientists, marketers and consumer scientists in researching convenience food, is suggested.

\section{- Me M Kok \\ - Prof P Botha \\ - Me AT Viljoen}

Departement Verbruikerswetenskap Universiteit van Pretoria 


\section{INLEIDING}

Verbruikers koop produkte wat vir hulle relevant is en wat aan hulle behoeftes en verwagtings voldoen (Asp, 1999; Garber et al, 2003; Messenger, 2003). Die siening wat verbruikers van 'n produk soos geriefsvoedsel het, verteenwoordig hulle persepsies daarvan (Shiffman \& Kanuk, 2000:122; Hawkins et al, 2001:285). Die persepsies wat verbruikers oor geriefsvoedsel vorm kan as sleutelaspekte in die voedselkeuse-proses beskou word. Navorsing oor verbruikerspersepsies kan ' $n$ belangrike rol speel om begrip te vorm vir hulle behoeftes en verwagtings van bepaalde produkte soos geriefsvoedsel. Kennis oor verbruikers se persepsies van geriefsvoedsel is nie alleen uit die oogpunt van die verbruiker belangrik nie, maar behoort ook as basis vir produkontwikkeling te dien. Messenger (2003) beweer dat nuwe voedselprodukte dikwels in die mark misluk omdat dit selde gebaseer is op die bevrediging van die ware behoeftes soos wat verbruikers se persepsies weerspieël. Garber et al (2003) wys die belangrikheid van verskillende verbruikersopinies uit, ofte wel verbruikers se positiewe en negatiewe persepsies, in die bemarking van sulke produkte. Kennis van die persepsies wat verbruikers het van die eienskappe wanneer geriefsvoedsel beoordeel word, is ook essensieel in die beplanning van gepaste verkoop- en promosie-strategieë asook om finansiële risiko vir die industrie te verminder (Spinks \& Bose, 2002; Reed et al, 2001). Daar behoort dus altyd 'n noue wisselwerking tussen die verbruiker, produkontwikkelaar en bemarker te wees.

Vroue as verbruikers wat voltyds ' $\mathrm{n}$ beroep beklee, ervaar tydsdruk vanweë hulle veelvuldige rolle (Candel, 2001; Reed et al, 2001). Maaltydbereiding is steeds in baie huishoudings die rol van die vrou (Davies,1997; Sloan, 1998). Daarom sou geriefsvoedsel as ' $n$ reddingsboei vir die beroepsvrou beskou kon word omdat die industrie ' $n$ deel van haar las kan verminder, en daar veronderstel word dat geriefsvoedsel, onder meer, arbeid- en tydsbesparend is. Die vraag ontstaan dus of beroepsvroue wel 'inkoop' in die gerief en tyd wat geriefsvoedsel hulle bied. Indien nie, wat staan in die pad daarvan?

Die doel van hierdie studie is om beroepsvroue se persepsies oor die produkeienskappe van geriefsvoedsels te begryp en te beskryf.

\section{TEORETIESE RAAMWERK}

Uit die doel van die studie is dit duidelik dat oor 'persepsie' en 'geriefsvoedsel' as konstrukte en 'beroepsvroue' as teikengroep, besin moet word.

\section{Persepsie}

Persepsie word beskou as die manier waarop ' $\mathrm{n}$ individu sy leefwêreld sien (Shiffman \& Kanuk, 2000:122; Hawkins et al, 2001:285). Meyer (1991:11) definieer persepsievorming as "...the cognitive process which obtains information from sensations in association with the processes of thought and meaning". Persepsies hou dus verband met die sintuiglike ervaring van ' $n$ produk, soos voedsel, waarvan die interpretasie as ' $n$ betekenisvolle, samehangende prentjie in die geheue van individue gestoor word (Shiffman \& Kanuk, 2000:123). Wanneer ' $n$ individu geriefsvoedsel eet, daarvan lees of hoor, word hierdie sintuiglike stimuli in die brein voortdurend verwerk en betekenis gegee. Die vorming van persepsies is ' $n$ kognitiewe proses (Olson, 1981:70; Sims, 1981). Derhalwe het hierdie studie 'n sosiaal-kognitiewe benadering. Krondl en Coleman (1988) sê dat verbruikers se persepsies oor voedsel hul voedselkeuses kan bepaal.

Die sintuiglike respons op voedsel verklaar egter slegs gedeeltelik die individu se keuse van ' $\mathrm{n}$ voedselproduk, wat daarop dui dat ander kognitiewe meganismes ook ter sprake is. Olson (1981:70-73) wys op die rol wat geheue - as ' $n$ interne kognitiewe meganisme - speel wanneer voedselkeuses gemaak word. Die individu se vorige ervarings met voedsel, wat as kennis in die geheue gestoor word, beïnvloed die wyse waarop nuwe inligting geprosesseer word. Die bestaande kennisstrukture is bekend as geheue-skemata (Krondl \& Coleman, 1988).

Tersaaklike aannames van die kognitiewe perspektief In hierdie studie word afleidings gemaak aangaande die inhoud van beroepsvroue se geheueskemata oor geriefsvoedsels, met ander woorde hoe hulle die eienskappe van geriefsvoedsel beoordeel teen die agtergrond van hulle vorige ervarings met geriefsvoedsel. Die volgende aannames van die kognitiewe perspektief word as vertrekpunt geneem:

- Mense is rasionele, denkende wesens wat sin probeer maak van die werklikheid rondom hulle (Baron \& Byrne, 1997:40). Die beroepsvrou, as verbruiker, is ' $n$ rasionele, denkende wese wat geriefsvoedsel waarneem en interpreteer binne haar eie bestaande kognitiewe raamwerke sodat sinvolle voedselkeuses binne konteks gemaak kan word.

- Verbruikers prosesseer eksterne stimuli deur middel van kognitiewe meganismes wat inligting ontvang en organiseer. Hoewel Olson (1981:70-73) die proses hiërargies voorstel, beklemtoon hy dat die proses nie heeltemal so eenvoudig verloop nie, omdat verskeie prosesse gelyktydig kan plaasvind en die tempo van betekenisgewing verskil. Eerstens word die stimulus geïdentifiseer, betekenis word daaraan gegee (enkodering) en dan word dit in die geheue-skemata as kennis gestoor (Olson,1981:71; Fiske \& Taylor, 1991:98; Baron \& Byrne, 1997:40). Geheue-skemata bestaan uit verworwe kennis en 'n organiserende raamwerk waarmee die nuwe kennis in verband gebring word. Nuwe skemata kan geskep word terwyl bestaande skemata onderling met mekaar verband hou (Olson, 1981:73; Krondl \& Coleman, 1988). Bestaande kennis, wat ook aspekte uit die eksterne omgewing soos kultuur, sosiale en interne invloed insluit, speel ' $n$ belangrike rol in die enkoderingsproses (Krondl, 1990:12). Kortliks behels dit dat persepsies gevorm word na ' $n$ sintuiglike er- 
varing met voedsel (sig, reuk, smaak, tas en gehoor) en dat die interpretasie daarvan in die geheue gestoor word.

Persepsies kan oor enige tipe eksterne stimulus, soos die verpakking of produkeienskappe, gevorm word. Wanneer ' $n$ individu met ' $n$ nuwe stimulus gekonfronteer word, word die geheue geskandeer en met die gegewe situasie in verband gebring, waarna die opsies geëvalueer en 'n keuse gemaak word. Die veronderstelling is dat wanneer ' $n$ individu oor geriefsvoedsel gepols word (soos tydens ' $n$ onderhoud), die kennis daarvan in die geheue geaktiveer word sodat 'n opinie uitgespreek kan word. Die kognitiewe meganismes (die geheue) help om sin te maak van die werklikheid, want dis hoe 'n verbruiker ' $n$ produk herken en produkeienskappe herroep. Persepsies is dimensioneel, daarom spreek ' $n$ verbruiker sy persepsies in terme van positiewe of negatiewe stellings uit.

- Kognitiewe meganismes help verbruikers om denkkortpaaie of heurismes te ontwikkel ten einde massas inligting so maklik moontlik te kan interpreteer (Baron \& Byrne, 1997:40). Geheue-skemata verwys na kognitiewe liasseerstelsels wat kennis oor ' $n$ konsep of ' $n$ stimulus stoor (Olson, 1981:75; Fiske \& Taylor, 1991:98) om sin van die leefwêreld te maak. Wanneer die individu in ' $n$ nuwe keusesituasie kom, word vorige ervarings met geriefsvoedsel 'onthou' en rig dit die individu se gedrag. As gevolg van ' $n$ leeftyd se ervarings met voedsel dien die geheue-skemata dikwels onbewustelik as verwysingsraamwerk om die keuse te vergemaklik (Sims, 1981; Krondl \& Coleman, 1988; Krondl, 1990:12; Zikmund \& d'Amico, 2001:164). Die persepsies in die geheue-skemata (positief en negatief) lei dus tot die vorming van denk-kortpaaie wat vinnige evaluerings, keuses of opinies moontlik maak. Produkte waarmee 'n verbruiker tevrede is, word dikwels herhaaldelik gekoop. Verbruikers dig dus dieselfde eienskappe aan soortgelyke produkte toe (ander geriefsvoedsels) en dit word deur Baron en Byrne (1997:770) protipering (stereotipering) genoem. Die assosiasies en kennis wat ' $n$ verbruiker van ' $n$ produk het, kan dus veroorsaak dat nuwe soortgelyke produkte op dieselfde manier as die bekende produk beoordeel word.

- Die redes vir gedrag word met behulp van attribusie verstaan. Die attribusieteorie verklaar hoe mense blaam of krediet aan gebeure toeskryf op grond van hul eie of ander se gedrag (Shiffman \& Kanuk, 2000:220). Baron en Byrne (1997:50) en Weiner (2000) beweer dat attribusie ' $n$ rol speel in die besluitnemingsproses van verbruikers. Hulle evalueer produkte wat hulle koop en besluit dan of hulle tevrede daarmee is al dan nie. Volgens Bem (in Kaiser, 1990:173) druk verbruikers hulle tevredenheid of ontevredenheid op twee maniere uit, naamlik deur woorde of die keuses wat hulle uitoefen. Sommige produkte leen hulle tot stabiele attribusies. Tevredenheid met ' $n$ produk lei daartoe dat dit keer op keer gekoop word (produklojaliteit). Ontevredenheid, byvoorbeeld met die smaak van 'n produk, lei daartoe dat die produk nie maklik weer gekoop sal word nie, omdat die verwagting bestaan dat die smaak weer dieselfde negatiewe reaksie sal ontlok. Omdat verbruikers ook in hierdie geval kan stereotipeer, behoort die voedselindu-strie belang te stel in verbruikers se persepsies, wat uiteindelik hulle lojaliteit teenoor produkte beïnvloed en as die dryfkrag van die voedselindustrie beskou kan word (Attwell, 2003).

Risikopersepsie of perseptuele vooroordeel is die onsekerheid wat verbruikers ervaar wanneer die gevolge van aankoopbesluite nie voorspel kan word nie (Zikmund \& d'Amico, 2001:157). In die studie van Reed et al (2001) is daar bevind dat die volgende aspekte die keuse en aankoop van voorbereide geriefsgeregte bepaal, naamlik gerief, smaak, prys, aanvaarding deur die gesin/huishouding en kwaliteit soos varsheid. Enige onsekerheid aan verbruikerskant oor die genoemde aspekte kan as 'n risikopersepsie beskou word.

Die mees algemene vorme van risikopersepsie, soos beskryf in Shiffman en Kanuk, (2000:153), word kortliks genoem en in verband gebring met moontlike risiko's wat verbruikers ten opsigte van die eienskappe van geriefsvoedsel kan ervaar.

- Funksionele risiko is die risiko dat die produk nie aan die funksionele verwagting sal voldoen nie, byvoorbeeld dat dit vinniger voorberei word of dat dit aan die smaak sal voldoen wanneer dit met tuisbereide produkte vergelyk word.

- Fisieke of veiligheidsrisiko is die risiko wat die produk vir die verbruiker of ander persone se gesondheid kan inhou. Verbruikers wat sensitief is vir byvoegings soos preserveermiddels, of bekommerd is oor higiëne (Manrique \& Jensen, 1998), mag moontlik fisieke of veiligheidsrisiko ervaar in die beoordeling van geriefsvoedsel.

- Finansiële risiko is die risiko dat die produk nie die prys werd is nie. Volgens Warde (1999) word geriefsvoedsel beoordeel in terme daarvan of dit waarde vir geld bied. Volgens Schaffner et al (1998:333) verwag verbruikers dat bepaalde produkte binne ' $n$ verwagte prysspektrum val, en indien die pryse daarbuite val, sal risikopersepsie ervaar word.

- Psigologiese risiko is die risiko dat die produk nie die verbruiker se ego sal streel nie.

\section{Geriefsvoedsel}

Geriefsvoedsel is soos volg gekonseptualiseer na oorweging van definisies uit die literatuur (Traub \& Odland in Capps et al, 1985; Krondl, 1990:10): Geriefsvoedsel is enige volledige of gedeeltelik voorbereide dis, voedselproduk of bestanddeel waarvan betekenisvolle voorbereidingstyd en/of kulinêre vaardighede en/of energie-insette vir die tuisteskepper deur die voedselindustrie gedoen is. 
Eienskappe van geriefsvoedsel Krondl (1990:12) noem sewe kategorieë van eienskappe waaroor persepsies aangaande geriefsvoedsel gevorm kan word, naamlik versadigingswaarde, toleransie of newe-effekte, smaak, gesondheidswaarde, prys, gerief, en prestige. Hierby kan voorkoms, verpakking en handelsmerk gevoeg word. Al hierdie aspekte word deur die verbruiker geïnterpreteer tot 'n sinvolle persepsie van die produk en die geskiktheid daarvan vir verskillende situasies. Beharrel en Denison (1991) asook Levy en Weitz (2001:155) wys daarop dat verbruikers na verskillende 'bondels' van eienskappe vir bepaalde produkte soek.

\section{Beroepsvroue}

Wêreldwyd werk vroue buitenshuis vir verskeie redes (Eshleman, 1994:118-119). Sloan (1998) voorspel dat hierdie tendens nie alleen sal toeneem nie, maar dat vroue meer as die tradisionele agt ure per dag sal werk. Selfs vroue met jong kindertjies betree die arbeidsmark. Beroepsvroue in hierdie studie word beskou as vroue wat minstens 40 ure per week professionele diens aan die samelewing lewer. Callahan (1988:31) definieer 'n professionele beroep as “...a profession (that) delivers esoteric services - advice or action or both - to individuals, organizations or government; to whole classes or groups of people or to the public at large". Om 'n professionele diens aan die samelewing te lewer is uitgebreide opleiding en intellektuele ontwikkeling noodsaaklik.

Uit die literatuur blyk dit dat die meeste vroue wat voltydse beroepe beklee, tydsdruk ervaar (Darian \& Cohen, 1995; Davies, 1997; Candel, 2001; Reed et al, 2001). Hulle tyd word meestal tussen huishoudelike, sosiale en werksverpligtinge verdeel. Maaltydbereiding is in baie huishoudings steeds die rol van die vrou (Gofton, 1995; Davies, 1997; Sloan, 1998). 'n Mens sou wou redeneer dat die groot verskeidenheid geriefsvoedsel 'n outomatiese keuse vir beroepsvroue behoort te wees om hul lewens te vereenvoudig en om gehalte tyd tuis te kan spandeer (Kinsey, 1997; Sloan, 1998; 1999; Zikmund \& d'Amico, 2001:67; Reed et al, 2001). Sommige navorsingsresultate dui egter op die teendeel (Gofton, 1995; Davies, 2001; Candel, 2001). Dit blyk dat vroue met hoër opleidingspeile skepties is oor geriefsvoedsel (Horton \& Campbell, 1991; Manrique \& Jensen, 1998). Beroepsvroue is krities ingestel op gesondheid, goeie voeding en veilige voedsel - vandaar dat dit nie ' $n$ outomatiese keuse is nie. Verbruikers mag ook negatiewe persepsies van geriefsvoedsel hê as dit nie genoegsame gerief bied nie (Candel, 2001). Omdat daar onsekerheid is oor die persepsies rondom geriefsvoedsel, ontstaan die vraag: "Wat is beroepsvroue se persepsies van die produkeienskappe van geriefsvoedsel en hoe rig hierdie persepsies die proses van keuse, aankoop en gebruik daarvan?"

Enkele aspekte wat beroepsvroue se persepsies mag rig, naamlik sintuiglike faktore, geslag, ouderdom en gesondheid, word vervolgens uitgelig:

- Sintuiglike faktore speel 'n alomteenwoordige rol in die aanvaarding of verwerping van voedsel. Die sintuie is alleen en in kombinasie met mekaar verantwoordelik vir die waarneming en interpretasie van die voorkoms, geur en tekstuur van voedsel (Cardello, 1996:63). Die sintuie is dus verantwoordelik vir die vorming van persepsies aangaande voedsel wat op ' $n$ kontinuum van byvoorbeeld aanvaarbaar/onaanvaarbaar realiseer. Die sintuiglike persepsie van voedsel is ook gewortel in dit wat kultureel, sosiaal sowel as ekonomies aanvaarbaar is (Krondl, 1990:12). Smaak word as een van die belangrikste faktore beskou wat die keuse van geriefsvoedsel beïnvloed en dien ook as een van Krondl (1990:12) se kategorieë wat persepsies oor voedsel rig.

- Geslag speel ook 'n rol in terme van sintuiglike aspekte, soos smaak, wat verskillend deur mans en vroue geïnterpreteer word. Vroue is oor die algemeen meer as mans besorg oor die kwaliteit en die gesondheidswaarde van voedsel, terwyl mans smaak belangriker ag (Bock et al, 1998; Reed et al, 2001).

- Ouderdom blyk ook die keuse van geriefsvoedsel te beïnvloed. Volgens Capps et al (1985), Manrique en Jensen (1997), Sloan (1998), Reed et al (2001) en Levy en Weitz (2001:116), is werkende vroue van alle ouderdomskategorieë potensiële kopers van geriefsvoedsel, veral jonger beroepsgerigte vroue en vroue met jong kinders (Darian \& Tucci, 1992; Madill-Marshall et al, 1995; Brech, 1998; Jae et al, 2000). Jongmense met min kennis en vaardigheid ten opsigte van voedselbereiding mag geriefsvoedsel as ' $n$ reddingsboei beskou.

Volgens Sloan (1998) is daar ' $n$ groeiende voorkeur vir gesonde eetgewoontes. Keuses word gemaak ten gunste van vars groente, vrugte sowel as grane as teenvoeter vir leefstylsiektes. Die verskeidenheid verwerkte vars groente wat deesdae beskikbaar is, kan moontlik ' $n$ bydrae lewer tot ' $n$ gesonder dieet vir almal in die huishouding (Mainland, 1998).

\section{NAVORSINGSONTWERP}

'n Ideografiese, kontekstuele navorsingstrategie (Babbie \& Mouton, 2001:272) is gevolg, aangesien 'n klein groepie beroepsvroue se unieke persepsies oor geriefsvoedsel in terme van hul oortuigings, agtergrond en konteks verstaan en beskryf wil word (Neuman, 2000:22; Babbie \& Mouton, 2001:xxvi, 271). Kwalitatiewe navorsingstegnieke is gekies omdat dit data van die verlangde aard vir die gestelde probleemstelling sou kon ontgin (Babbie \& Mouton, 2001:270)

\section{Deelnemers}

Beroepsvroue, wat minstens 40 ure per week professionele diens lewer, is gekies vir die volgende redes:

- Vanweë hul akademiese opleiding kan hulle waarskynlik met gemak hul persepsies van geriefs- 
voedsel kommunikeer.

- Vroue wat ten minste 30 uur per week werk en tydsdruk vanweë hul veelvuldige rolle ervaar (Gofton, 1995; Candel, 2001; Davies, 2001), is 'n potensiële teikenmark vir geriefsvoedsel.

- Vroue, soos blyk uit die literatuur en eie ervaring, neem steeds die grootste verantwoordelikheid ten opsigte van die aankope en bereiding van voedsel (Davies, 2001).

Steekproeftrekking Doelbewuste steekproeftrekking (Strydom \& Venter, 2002:207; Babbie \& Mouton, 2001:166) waarbinne vrywilligers gewerf is, is toegepas (Babbie \& Mouton, 2001:277). Uit die literatuur is situasies geïdentifiseer wat die keuse, aankoop en gebruik van geriefsvoedsel tot ' $n$ mindere of meerdere mate mag rig. Daar is dus doelbewus gepoog om vrouens wat hulself in een of meer sulke situasies bevind, in die steekproef in te sluit:

- Enkellopendes.

- Huishoudings sonder kinders (Candel, 2001).

- Huishoudings met klein kindertjies aangesien kindertjies se versorging hoë eise aan hul ouers stel (Madill-Marshall et al, 1995; Brech, 1998; Jae et al, 2000).

- Verskillende ouderdomsgroepe wat sg. Generasie $X$ en 'Baby Boomers' insluit, omdat persone uit dieselfde generasie dikwels dieselfde aankooppatrone openbaar (Levy \& Weitz, 2001:-113-116). Generasie X is die eerste generasie wat grootgeword het met geriefsvoedsels (Sloan, 1998). 'Baby Boomers' verteenwoordig ' $\mathrm{n}$ generasie wat beperkte ondervinding met geriefsvoedsel het.

- Belangstelling in voedsel en vaardigheid met voedselbereiding kan moontlik ' $n$ invloed op die keuse en gebruik van geriefsvoedsels hê. Die aanname is dat persone wat vaardig is met voedselbereiding, geriefsvoedsel krities sal beskou.

- Verbruikers met ' $n$ hoër opleidingspeil se response is waarskynlik meer gefokus en akkuraat, aangesien hulle in staat is om die onderliggende redes vir hulle keuse te verbaliseer (Somasundaram,1993).

'n Beskrywing van die agt deelnemers word in Tabel 1 aangedui.

\section{Data-insameling}

Individuele onderhoude en 'n projektiewe tegniek is gebruik om data in te samel. Verskillende tegnieke van data-insameling vul mekaar aan en dien as kruisvalidering om die geloofwaardigheid van die data te verhoog (Leedy \& Ormrod, 2001:105; Babbie \& Mouton, $2001: 275,278)$. Die data wat met die verskillende tegnieke ontgin is, is met mekaar vergelyk en in een datastel geïntegreer.

'n Onderhoud is ' $n$ doelgerigte gesprek rondom ' $n$ spesifieke onderwerp tussen ' $n$ onderhoudvoerder en ' $n$ deelnemer (Greeff, 2002:292; Neuman, 2000:273; Babbie \& Mouton, 2001:289; Botha, 2001). Twee individuele onderhoude is met ses deelnemers gevoer. Twee deelnemers was nie beskikbaar vir ' $n$ tweede onderhoud nie. Die onderhoude is in die deelnemers se huise of kantore gevoer op tye wat vir hulle geleë was (Lautman, 1982; Lawless \& Heyman, 1998:528; Babbie \& Mouton, 2001:292). Die deelnemers is vooraf verseker dat hulle opinies oor geriefsvoedsel, hetsy positief of negatief, waardevol vir die studie sou wees en dat daar geen regte of verkeerde antwoorde is nie. Die onderhoude is met toestemming op oudioband opgeneem (Babbie \& Mouton, 2001:277) sodat die oorspronklike data behoue kon bly. Die onderhoude het elk gemiddeld 'n uur geduur.

Temas (sien hieronder) het die gesprek gefasiliteer sonder om die gesprek te lei of te beperk (Babbie \& Mouton, 2001:273), maar ook om te verhoed dat die gesprek afdwaal en onnodige tyd verkwis word. Interpretasies van die navorser is met die deelnemers geverifieer (Babbie \& Mouton, 2001:277, 289). Gesprekvoering is volgehou totdat die navorser seker was dat inligting oor al die relevante aspekte ingewin is, ter wille van die geloofwaardigheid van die data (Calder in Lautman, 1982; Leedy \& Ormrod, 2001:106; Lawless \& Heyman, 1998:525; Babbie \& Mouton, 2001:277).

Die temas waaroor deelnemers gepols is, was die volgende:

- Hulle algemene persepsies van geriefsvoedsel.

- Eienskappe van die produkte wat as belangrik geag word en wat lei tot aankope.

- Die redes waarom bepaalde produkte onaanvaarbaar is en dus nie gekoop of weer gekoop sal word nie (om moontlike risikopersepsie te bepaal of

TABEL 1

DEMOGRAFIESE EIENSKAPPE VAN DIE DEELNEMERS $(n=8)$

\begin{tabular}{|l|l|l|l|}
\hline Deelnemer en beroep & Ouderdomsgroep & Huwelik-status & Kinders \\
\hline Personeelbestuurder & Generasie X & Enkel & Geen \\
\hline Lektrise & Generasie X & Enkel & Geen \\
\hline Inligtingkundige & 'Baby boomer' & Enkel & $\begin{array}{l}3 \text { volwasse kinders wat op } \\
\text { hul eie woon }\end{array}$ \\
\hline Lektrise & Generasie X & Getroud & Geen \\
\hline Lektrise & Generasie X & Getroud & 2 klein kinders onder 6 jaar \\
\hline Personeelbestuurder & Generasie X & Getroud & $\begin{array}{l}3 \text { klein kinders, eerste pas } \\
\text { skool toe }\end{array}$ \\
\hline Lektrise & Generasie X & Getroud & 2 klein kinders, onder 5 jaar \\
\hline Onderwyskundige & 'Baby boomer' & Getroud & $\begin{array}{l}2 \text { volwasse kinders waarvan } \\
1 \text { tuis woon }\end{array}$ \\
\hline
\end{tabular}


eienskappe wat ontbreek, te ontdek).

- Hulle persepsies van veiligheid en voedingswaarde van geriefsvoedsel tydens aankope.

Kasregisterstrokies is as addisionele databron gebruik om die aankope van geriefsvoedsel te bevestig. Veldnotas is tydens en na die onderhoude gemaak, wat die navorser se indrukke van die gesprek, die deelnemer, en konseptuele en teoretiese notas ingesluit het (Oakley, 1981:31; Decrop, 1999; Babbie \& Mouton, 2001:275). Veldnotas dra by tot die bevestigbaarheid van die data (Guba en Lincoln in Babbie \& Mouton, 2001:278). Hierdie data is by die verbatim-transkriberings gevoeg.

Projektiewe tegnieke word soos volg gedefinieer: "Projective techniques provide verbal or visual stimuli which, through their indirection and concealed intent, encourage respondents to reveal their unconscious feelings and attitudes without being aware that they are doing it" (Will et al, 1996:38). Volgens dié skrywers, verskaf verbruikers soms vals of misleidende antwoorde, wanneer hulle op die man af oor produkte uitgevra word. Met projektiewe tegnieke word die kollig van die deelnemer weggeneem, wat deelnemers in staat stel om hul dieperliggende opinies te lug sonder die vrees van ' $n$ persoonlike ontbloting (Hollander, 1988; Will et al 1996; Catteral \& Ibbotson, 2000). Deelnemers deel gevoelens en sienings dus op indirekte wyse mee. Projektiewe tegnieke is ' $n$ sinvolle tegniek aangesien dit deelnemers motiveer om ' $n$ binne-perspektief te gee, in plaas van stereotipiese antwoorde (Solomon, 1994:25). Dit dra by tot die geloofwaardigheid en geldigheid van die data wat tydens die onderhoud ingewin is (Lawless \& Heyman, 1998:534; Decrop, 1999).

Vir die doel van hierdie studie is ' $n$ konstruksieprojektiewe tegniek ontwerp wat die deelnemers na die eerste onderhoud in hul eie tyd kon voltooi. Die deelnemers is versoek om ' $n$ konsep-televisieadvertensie vir geriefsvoedsel te formuleer waarin die teikengroep, beskrywing van die produk en die storielyn of idee uiteengesit moes word. Die teikengroep wat die deelnemer gekies het, is vergelyk met haar eie demografiese profiel, soos haar huwelikstatus, ouderdom en kinders. Die produkte wat gekies is en die eienskappe wat genoem is, is vergelyk met die tipe produkte wat sy koop. Die storielyn is gebruik om iets van haar identiteit te wete te kom en dit in verband te bring met wat sy tydens die onderhoud genoem het. Daar is gekontroleer of hierdie data die deelnemer se algemene positiewe of negatiewe persepsie van geriefsvoedsel weerspieël.

\section{Data-analise}

Data-analise is volgens die stappe van ' $\mathrm{n}$ 'grounded theory'-benadering gedoen (Neuman, 2000:145-146; Babbie \& Mouton, 2001:498-501; De Vos, 2002a:345351). Strauss en Corbin in Babbie \& Mouton (2001:498) definieer 'grounded theory' soos volg: "A grounded theory is one that is inductively derived from the study of the phenomenon it represents. That is, it is discovered, developed and provisionally verified through systematic data collection and analysis of data pertaining to that phenomenon. Therefore, data collection, analysis and theory stand in a reciprocal relationship with each other. One does not begin with a theory, then prove it. Rather, one begins with an area of study and what is relevant to that area is allowed to emerge." Die kern van die benadering is dus dat eerste-orde konsepte uit Wêreld 1 (die leefwêreld van die oningewyde) (Babbie \& Mouton, 2001:7) gebruik word om letterlik ' $n$ teorie van die grond af op te bou. Oop, spil- en selektiewe kodering is gebruik. Oop kodering behels die kategorisering van dele van die datastel. Vir elke kategorie kan dimensies en indikatore ook geïdentifiseer word. Met spilkodering word die kategorieë binne konteks geplaas, terwyl met selektiewe kodering ' $n$ kategorie stelselmatig met ander kategorieë in verband gestel word, die verwantskap gevalideer word en moontlik verder verfyn word om sodoende by ' $n$ nuwe samehang of die verfyning van ' $n$ teorie uit te kom.

\section{RESULTATE EN BESPREKING}

Uit die aard van die navorsingsontwerp van die studie kan geen veralgemenings oor die data gemaak word nie. Dit word slegs in diepte beskryf (De Vos, 2002b:46). Die resultate en bespreking moet dus in hierdie konteks gelees en geïnterpreteer word. Weens lengtebeperkinge word daar volstaan met enkele verbatim-aanhalings as bewyse van die data.

Die analise en interpretasie van die data is teen die agtergrond van die volgende teoretiese raamwerk gemaak: positiewe of negatiewe persepsies van geriefsvoedsel is die gevolg van ' $n$ evalueringsproses wat begin tydens die aankope daarvan, maar veral verloop nadat die produk gekoop is, met ander woorde wanneer dit voorberei (indien nodig) en geëet word. Verskillende eienskappe word dus teen mekaar opgeweeg (Furst et al, 1996) wanneer die produk gekoop, voorberei en geëet word. Tevredenheid met ' $n$ produk of bepaalde eienskappe lei tot positiewe persepsies wat weer tot lojaliteit teenoor 'n produk lei. Ontevredenheid lei tot negatiewe persepsies en veroorsaak dat ' $n$ bepaalde produk nie maklik weer gekoop sal word nie. Die eienskappe wat vir die deelnemers tevredenheid of ontevredenheid tot gevolg gehad het, sluit die volgende in: prys, smaak, gerief, voorkoms, gesondheidswaarde, kwaliteit en veiligheid. Behalwe vir toleransie wat nooit ter sprake was nie, stem die eienskappe ooreen met Krondl (1990:12) se lys van persepsies oor voedsel. Die onderskeie eienskappe word egter nie in isolasie beoordeel nie, wat veronderstel dat daar onderlinge interaksie tussen die eienskappe bestaan.

\section{Prys}

Daar kan aanvaar word dat die deelnemers bereid is om die prys te betaal vir dié geriefsvoedsels wat hulle wel aankoop. Enkele spesifieke verwysings na die prys van geriefsvoedsel is deur die deelnemers ge- 
maak deur woorde te gebruik soos: 'duur', 'redelik bekostigbaar', 'redelik' en 'regardless die prys'. Hierdie woorde is met behulp van oop kodering as 'prys' gekodeer. Prys word egter selde in isolasie beskou en daarom is spil- en selektiewe kodering gebruik om die verwante aspekte soos die smaak, die hoeveelheid porsies wat ' $n$ produk bied en die geriefswaarde van produkte met prys in verband te bring. Beharrel en Denison (1991) het ook gevind dat verbruikers na verskillende 'bondels' eienskappe van produkte kyk.

Prys en smaak Positiewe persepsies word aan die prys van bepaalde produkte geheg as die smaak daarvan vir die deelnemer aanvaarbaar is, en dit bring ' $n$ bereidheid mee om geld daarvoor te verruil. Dit hang ook saam met die feit dat sekere produkte nie maklik self deur die deelnemers gemaak of voorberei kan word nie, soos dat nie maklik haalbaar is vir persone wat voldag werk en in stede woon om ertjies (petit pois) self te kweek nie. "... daar is sekere produkte wat ek koop, 'regardless' die prys. ... ek sal byvoorbeeld ... petit pois koop ..."

Verder, oor tyd heen, word positiewe persepsies oor ' $n$ produk versterk in die geheue-skemata, sodat die deelnemers seker is dat die produkte aan hulle verwagtings sal voldoen (die attribusieproses) en gevolglik bereid is om ' $n$ prys daarvoor te betaal.

"Pizza koop ons graag by 'n pizza plek - dis vir ons lekker, hulle maak lekker pizzas ..."

Die smaak van geriefsprodukte word ook vergelyk met bestaande skemata van die tuisbereide ekwivalente en as die smaak nie goed daarmee vergelyk nie, word die gereg eerder self voorberei om te verseker dat dit 'reg' smaak. Daar kan geargumenteer word dat funksionele en finansiële risikopersepsie vermy word as hierdie produkte eerder self berei word, want produkte wat 'sleg' smaak, is ook 'n mors van geld.

"[Lasagne] is vir my duur in vergelyking om dit self te maak - vir die smaak wat jy kry."

Prys en gerief Die prys van geriefsprodukte word deur sommige deelnemers ( $a, b, d$, e en $h$ ) opgeweeg teen die koste van die individuele bestanddele en die voorbereiding daarvan. Positiewe persepsies ontstaan as die persoonlike insette wat nodig is om dieselfde produk te lewer goed opweeg teen die voordele wat die geriefsproduk bied.

"Maar ek dink die pryse op hierdie stadium is redelik baie van die goed soos $X X X$... (gemengde gevriesde groente) - as jy hom klaar apart gaan koop en sny en goeters, dan werk dit jou omtrent amper meer uit."

In die geval van geregte of produkte wat deelnemers (c, $g$ en $h$ ) met min moeite en dikwels goedkoper self kan voorberei, word die geriefsalternatief nie as positief ervaar nie. Die koste van hul persoonlike insette en tyd weeg dus nie meer as die prys wat daarvoor gevra word omdat dit deur die industrie gedoen is nie. "En dit (mengelslaai) is bietjie duur, en dis nie te veel moeite om " $n$ tamatie te sny en 'n blaartjie daarby." "... goed wat ek nie sal koop van die klaar goed, is soos 'n makaronidis - dis so maklik om self te maak ..."
Prys en aantal porsies Hoewel die pryse van produkte en geregte nie presies bereken word deur sommige deelnemers ( $f, g$ en $h$ ) nie, bestaan daar ' $n$ algemene 'aanvoeling' van die koste van die produk of gereg of word dit teen ' $n$ eie norm wat in die geheueskemata vasgelê is, beoordeel.

"Ek werk die vleiskoste vir die ete (uit) - vir ons elke dag is (dit) so tussen R10 en R20. So ek kyk dat ek naastenby in daai omgewing koop. Nie dat ek so fyn uitwerk nie, maar ..."

Positiewe persepsies oor die prys van 'n geriefsproduk of -gereg bestaan wanneer die hoeveelheid of porsiegrootte daarvan voldoende is vir die aantal mense wat daarvan moet eet. Geriefsgeregte word dikwels as individuele porsies bemark en van die deelnemers wat vir ' $n$ hele gesin moet kosmaak, sien dit as negatief aangesien ' $n$ paar pakkies in plaas van een groot gereg, gekoop moet word om te verseker dat almal genoeg kry. Die prys van die individuele porsies is baie hoog teenoor ' $\mathrm{n}$ gereg wat tuis berei kan word wat genoeg vir al die maaltydgangers sal wees.

"Dit (lasagne) lyk vir my te duur, ... ek ken nie eers ordentlik die pryse nie - dit lyk vir my duur ... want as jy byvoorbeeld daai lasagnas - so ' $n$ kleintjie - en laas toe ek gekyk het was dit so R10 of selfs nog duurder en dan voel dit vir my ek (moet ' $n$ ) klomp klein pakkies koop om vir almal in die huis kos te gee."

In teenstelling daarmee, lei groter hoeveelhede dikwels tot vermorsing vir enkellopende persone. Om ' $n$ gereg van meet af voor te berei en al die bestanddele daarvoor aan te koop, terwyl slegs een porsie daarvan benodig word, kan weer vir die enkellopende duurder wees as om die geriefsgereg of -produk aan te koop.

“... omdat ek 'n enkel persoon is en ek nie nodig het om grootskaals te koop nie ... dink ek dit (geriefsvoedsel) sal baie duurder uitwerk as mens vir " $n$ hele gesin moet koop."

Dit is duidelik dat daar ' $\mathrm{n}$ verband tussen die prys, smaak en die 'gerief' van geriefsvoedsel bestaan. Die geriefsproduk word vergelyk met ' $n$ norm van hierdie eienskappe in die geheue-skemata en smaak blyk die prominentste te wees. Hierdie vergelyking rig die persepsie van die produk, hetsy positief of negatief. Dit sou dus in die voedselindustrie se belang wees om besondere aandag aan hierdie drie eienskappe te skenk in die ontwikkeling van geriefsvoedselprodukte. Prys tree egter ook in interaksie met die eienskappe soos voorkoms, gesondheidswaarde en kwaliteit van die produk, wat elk onder aparte opskrifte bespreek word.

\section{Smaak}

Die deelnemers plaas ' $n$ hoë premie op die smaak van geriefsprodukte en hulle maak blykbaar van attribusie gebruik om hul besluite te regverdig. Krondl (1990:11-12), Furst et al (1996), Reed et al (2001) en Neall (2003) sonder smaak as ' $n$ belangrike eienskap 
van geriefsvoedsel uit. Die verbatim-aanhalings waarin woorde soos 'vreeslik lekker', 'dit proe soos', 'dit smaak vir my', 'lekker gegeurde', 'dit smaak na', ' nie lekker nie' voorkom, is gebruik om smaak te kodeer. Smaak is ook deur middel van spil- en selektiewe kodering met aspekte wat daarmee verband hou, verbind en dit word as sodanig bespreek.

Die smaak van geriefsprodukte word vergelyk met die smaak van tuisbereide ekwivalente Daar is vasgestel dat die deelnemers die smaak van geriefsgeregte en produkte met die smaak van tuisbereide ekwivalente vergelyk. As die smaak van die geriefsproduk goed vergelyk met die norm wat in die geheue-skemata gestoor is, is die persepsie van die smaak en van die produk in die algemeen positief.

"Dit (pasta-met-sous) smaak vir my dieselfde (as tuisbereide), daar is nie regtig vir my ' $n$ groot verskil nie ..."

As die smaak van ' $n$ geriefsproduk enigsins afwyk van die verwagting by die beoordeling daarvan, veroorsaak dit dat die produk nie sommer weer gekoop sal word nie. Dit is dan asof beide funksionele en finansiële risikopersepsie geaktiveer word om 'n soortgelyke negatiewe ervaring (of risiko) in die toekoms te vermy.

"... ek sal gewoonlik ietsie wat interessant lyk koop en as mens dit geproe het en dit proe nie lekker nie - dit proe pakkierig of plastiekerig of boksierig - dan sal ek dit nie weer koop nie."

Oor die algemeen lyk dit nie of die deelnemers (a, e en g) positiewe persepsies oor die smaak van geriefsgeregte soos lasagne en herderspastei het nie. Lae gebruiksfrekwensie van bevrore hoofgeregte, weens 'n onaanvaarbare smaak, word ook deur Darian en Cohen (1995) en Vickers (1999) gerapporteer. Smaak en geur word as belangriker beskou as gerief, gesondheid of prys (Reed et al, 2001; Neall, 2003).

\section{Aanpassing van die smaak van geriefsprodukte} Aangesien individue se smaakvoorkeure verskil, blyk die deelnemers positief te wees oor produkte wat hulle self na gelang van eie of gesinsvoorkeure kan geur. Sulke produkte ontlok positiewe persepsies.

“... sê nou maar pizzas of sulke goeters wat ons sommer net vinnig kan eet, sal ek nog self my eie mushrooms en eie kaas en alles nog bietjie bysit om die smaak meer - ja dit gaan hoofsaaklik oor die smaak ... partykeer kort dit net daai ietsie wat dit meer tuisgemaak laat proe."

Die smaak van ekwivalente geriefsprodukte word met mekaar vergelyk Pizzas wat as wegneemetes gekoop of in restaurante bestel word, word as norm gebruik om pizzas wat tuis in die oond gebak moet word, mee te vergelyk.

"Ons het byvoorbeeld al van die pizzas gekoop wat jy self in die oond sit - wat ongelooflik sleg was - ek sal dit nooit weer koop nie. As dit lekker was, sou mens dit kon oorweeg om dit weer te koop vir ' $n$ Vrydagaand of so, maar dit was so sleg dat ek dit nie weer sal koop nie."
Die afleiding is dus dat hierdie deelnemer (f) eerder sal voortgaan met haar gebruik: "Pizza koop ons graag by die pizza-plek ..." Die moontlikheid bestaan dat sy nou pizzas wat nog verhitting tuis benodig, stereotipeer met ' $n$ onaangename smaak en eerder die risiko daarvan in die toekoms sal vermy, selfs al kos dit vir haar duurder om die pizza te koop wat gereed is om te eet. Dit is ook opvallend dat die norm van pizza, 'n relatief onlangse gunsteling vir SuidAfrikaners, eerder dit is wat by die 'pizza-plek' gekoop word as dit wat tuis berei word.

Die moontlikheid om te kan kies uit ' $n$ verskeidenheid geure Deelnemers eksperimenteer met geriefsprodukte binne 'n reeks, soos vis wat gedifferensieer is ten opsigte van geur, om vas te stel waarvan hulle die meeste hou. Die geurvariasies by produkte veroorsaak dat maaltye interessant bly en verskaf afwisseling, maar verseker ook dat die deelnemers ' $n$ keuse het.

"B... het 'n groot verskeidenheid - lekker gegeurde vis." "... party geure is lekkerder en ander is minder lekker."

Smaak en tekstuur Soms word negatiewe persepsies ( $a$ en b) oor die smaak van 'n produk gevorm terwyl dit eintlik die tekstuur van die produk is wat nie aan die verwagtings voldoen nie.

"Ja ... mens kry hierdie pakke met die aartappelskyfies in wat jy net kan bak - ek het gevind dis glad nie lekker nie (deelneemer meen dit proe korrelrig) en ook soetpatats, die gevriesde soetpatats is ook nie vir my lekker nie. Ek sal dit eerder van vars produkte maak."

Sommige styselbevattende groentesoorte, soos aartappels, word melerig wanneer dit gevries word. Sulke stysels kan nie aan chemise modifikasie, soos beskryf in Bennion en Scheule (2000:250), onderwerp word om dit vir bevriesing geskik te maak nie. Dit is juis hierdie afname in die kwaliteit van sekere gevriesde produkte se tekstuur wat negatiewe persepsies ontlok en veroorsaak dat vars produkte voorkeur kry.

Die persepsie dat die maalvleis in geriefsgeregte nie soos maalvleis smaak nie, hou ook verband met die tekstuur daarvan en ook met die persepsie dat sojaprodukte gebruik word om die maalvleis te 'rek'. Wanneer deelnemers redes vir hulle ontevredenheid soek, kan dit aan die attribusieproses, volgens Weiner (2000), toegeskryf word.

"... daai maalvleis proe nie soos maalvleis nie ...dis seker, wat's hierdie ander goed (soja) wat jy maak?"

\section{Gerief}

Die eienskap 'gerief' het verskillende betekenisse vir die verskillende deelnemers. Woorde wat met gerief verband hou, soos 'een-stap-goed', 'vinnig kan gaarmaak', 'as ek haastig is', 'makliker' is eerstens gekodeer. Daarna is die konsepte ontleed om die betekenis van gerief te bepaal. Gerief behels onder andere die tyd en die moeite wat gespaar word met die voorbereiding van geregte asook met die aankoop van bestanddele (in die geval van produkte wat uit ' $n$ 
verskeidenheid bestanddele saamgestel is). Gerief behels ook die spaar van kognitiewe energie, byvoorbeeld waar die geriefsproduk ' $n$ maaltyd op sy eie verteenwoordig en daar nie gedink hoef te word wat om daarby te bedien nie.

Persepsies oor tyd en moeite (arbeid) wat gespaar word met geriefsvoedsel Die deelnemers, wat almal tydsdruk ervaar, maak veral van geriefsprodukte gebruik wanneer hulle maaltye moet voorberei. Die tyd en fisiese energie wat hulle daarmee spaar, blyk die belangrikste redes te wees vir die keuse van die spesifieke geriefsvoedselsoorte.

“... hierdie een-stap-goed wat jy vinnig kan maak, werk vir my die beste, want soos ek sê, ek kom party middae sesuur by die huis en dan moet ek gou kos maak. So die goed wat klaar gesny is, klaar reg is, tipe van wat jy net vinnig kan gaarmaak. Kaassous, mushroomsous, pepersous en dan ja hierdie spaghetti bolognese souse, in die botteltjies, en jy gooi dit net by maalvleis."

Sekere produkte verg moeite en dus meer tyd om voor te berei as ander. Groente word normaalweg eers voorberei deur dit te skil en kleiner te sny voordat dit gaargemaak word. Die voorbereiding van gevriesde groente is reeds gedoen en die blansjeringsproses wat in die industrie toegepas word om ensiemwerking wat agteruitgang in geur, kleur en smaak veroorsaak (Bennion \& Scheule, 2000:687) te beperk, verkort die gaarmaaktyd. So ook blyk hoender- en visporsies, veral dié met vulsels, krummellae of sous, gunstelinge by van die deelnemers $(a, b, c, e, f)$ te wees wanneer tydsdruk ervaar word.

"... dis net makliker omdat dit klaar in gesnyde formaat is en halfgaar is, so jy kook nie lank daaraan nie." "Ek gebruik baie geriefsvoedsel, soos daai chicken kiefs wat mens net vinnig in die oond druk en terwyl dit bak kan mens nog gou ander werk klaar maak en doen."

Sommige groentesoorte neem betreklik lank om gaar te word en kan nogal morsig wees, byvoorbeeld beet wat alles verkleur. Dit is dus logies dat sleur- en morsige take na die industrie gekanaliseer word.

"Ek koop partykeer die slaai in pakkies - ek weet dis duur, maar om beet te gaan kook en jou hele stoof vuil te mors en alles vuil te mors is daai beet in die pakkies lekker en ook (dié) in die bottetjies."

Die voorbereiding van sekere vleisprodukte, soos sosaties, is redelik arbeidsintensief aangesien ' $n$ marinade voorberei moet word, die vleis in blokkies gesny en gemarineer word, waarna dit op sosatiestokkies geryg word. Die tyd en moeite word deur deelnemers (c en e) ontsien en daarom word sosaties eerder gekoop.

"Ek sal nie self ' $n$ sosatie maak en dit marineer nie dis vir my makliker as dit klaar daar is."

Gereed-om-te-eet-geregte bied heelwat voordele vir bepaalde deelnemers ( $a$, $b$ en $d)$, naamlik baie minder skottelgoed en minder moeite om die geregte voor te berei en gaar te maak, asook dat ' $n$ maaltyd gouer gereed is.
"Weet jy, die skottelgoed - daar spaar ek baie, maar ook die bereiding self. Om voedsel op die stoof te sit en rond te hardloop en elke 10 minute te moet kyk is dit nog vir my wat nie baie goed is (met voedselbereiding nie), spaar ek baie tyd daarmee."

Dit is in ooreenstemming met die literatuur (Darian \& Cohen, 1995; Davies, 2001) dat vroue wat tydsdruk ervaar, tyd- en energiebesparende produkte wat goed smaak, aankoop. ' $n$ Deelnemer (b) se negatiewe persepsie oor ' $n$ geriefsproduk wat nie werklik tyd en moeite met die bereiding daarvan spaar nie, veroorsaak dat sy die betrokke produk nie weer sal koop nie. Volgens Candel (2001), sal beroepsvroue wat tydsdruk ervaar, nie noodwendig geriefsprodukte gebruik wat nie genoegsame gerief bied nie.

"Aanmaak-pannekoek - ek het dit eenkeer probeer ... en toe besef ek jy doen net soveel moeite soos om dit van die begin af te maak, as om daai pakkie te koop."

Kognitiewe energie wat gespaar word Deelnemers ( $a, b, c$ en $d$ ) het positiewe persepsies oor geriefsprodukte as hulle nie hoef te dink wat om daarmee saam te bedien vir aandete nie. Die produk is feitlik ' $n$ maaltyd op sy eie en as iets soos ' $n$ slaai daarby geëet word, voldoen die ete aan die standaard of norm van aandete wat in die geheue-skemata vasgelê is.

"Jy maak (vis met sous) sommer in die mikrogolf gaar en jy sit 'n slaaitjie daarby en dan het jy 'n hele ete."

Dit is nog makliker om na ' $n$ winkel / restaurant te gaan en ' $n$ hele maaltyd klaar te koop sonder om ' $n$ vinger te verroer of te dink watter bestanddele benodig gaan word vir maaltydbereiding. Die keuses word vinnig gemaak uit die beskikbare voedsels en ook teen die agtergrond van wat die vorige dae geëet is.

"Wel, daar is geen voorbereidingstyd vir my nie. Dit vat vyf tot tien minute om daar langs te ry en jy het ' $n$ hele ete. En dit laat my met baie tyd oor om my werk te kan doen of om sommer net te ontspan na ' $n$ harde dag se werk."

Gofton (1995) voorspel dat, namate die waarde van beroepsvroue se tyd toeneem, hulle meer kere maaltye sal koop in plaas daarvan om dit self te berei. Dit stem ooreen met bogenoemde resultate. Tydsdruk, wat een van die gevolge is wat betaalde arbeid vir individue meebring, gee dus aanleiding tot ' $n$ geriefsoriëntasie (Candel, 2001).

Geurmiddel-mengsels waarmee gewone bestanddele, soos rys byvoorbeeld, maklik in ' $n$ interessante gereg berei kan word, is gewild. Die samestelling van ' $n$ verskeidenheid geurmiddels spaar die maaltydbereider heelwat kognitiewe energie: sy hoef glad nie te wonder watter geurmiddels die beste sou wees, veral wanneer kennis en ondervinding skraps is nie. Davies (2001) verwys ook na kognitiewe energie wat gespaar word wanneer geriefsvoedsel gebruik word:

"... pakkies wat mens koop met die verskillende geure - daar is hoendergeur en groentegeur. Ek voel dis vir my baie vinniger en makliker as wat ek self geurmiddels moes aanmaak." 
Persepsies oor die voordele van saamgestelde produkte Saamgestelde produkte veronderstel produkte wat uit 'n verskeidenheid verwerkte bestanddele saamgestel is, onder andere bevrore gemengde groente, slaaisous, pasta-en-sous en vele ander. Voedselaankope word vergemaklik aangesien 'n enkele produk gekoop word, in plaas van afsonderlike bestanddele.

"Ek koop net daai gevriesde groente ... die mielies en die boontjies - wat ' $n$ mengsel is en dan koop ek dit omdat dit klaar gemeng is en dan lekker is om in kerrie en rys of stowegereg of so iets te gebruik. ... ek sou nie elkeen van die goed apart gaan koop en meng nie - dis net vir daai rede wat ek dit koop."

Veral die enkellopende deelnemers het aangedui dat hulle baat vind by saamgestelde geriefsgeregte, soos individuele mengelslaaie, weens minder vermorsing en minder bergingsruimte in beslag geneem in die kleiner kombuise van meenthuise.

"... dit is nie vir my die moeite werd (om 'n hele komkommer of slaaikop te koop nie) omdat ek 'n enkelpersoon is wat baie reis en dit word gou sleg in die yskas. Ek kan nie ' $n$ hele komkommer in ' $n$ aand of in twee dae opeet nie." "Ek koop 'n sout-enpepermengsel, roosmarynsout en ek het 'n pynappel en gerookte sout kombinasie ... dit spaar ook pakplek, want my kombuis is klein."

Sloan (1999) maak melding van Amerikaners wat poog om hulle lewens te vereenvoudig en graag eenskottelgeregte maak. Saamgestelde produkte kan dus ' $n$ bydrae lewer om professionele vroue se lewens in dié opsig te vereenvoudig.

Volgens Darian en Cohen (1995) word die konstruk 'gerief' dikwels in die literatuur as slegs eendimensioneel uiteengesit, naamlik die tydsbesparende aspek daavan. Die persepsies van die deelnemers gee insig in die tipe geriefsvoordele waarna verbruikers soek.

\section{Voorkoms}

(Geriefs)voedsel word eerste met die oë waargeneem alvorens dit geproe word. Voorkoms in die vorm van visuele leidrade, word gebruik om eienskappe soos kwaliteit, smaak, tekstuur en prys te bepaal (Imram, 1999; Kupiec \& Revell, 2001). Woorde soos 'vars', 'mooi', 'bleek', 'netjies opgesny', 'kleur' en 'dit lyk soos' is as voorkoms gekodeer.

Voorkoms, kleur en netjiese snitte Wat groente betref, word voorkoms beoordeel op grond van die kleur en die varsheid van die produk. Vars groente se kleur is normaalweg helder wat op goeie kwaliteit dui. Voorbereide, vars groente word ook deur sommige deelnemers ( $b$ en $h$ ) beoordeel op grond van die netheid en eenvormigheid waarmee die snitte, byvoorbeeld julienne, gesny is. Positiewe persepsies van die voorkoms bestaan as die produk aan die verwagtings en standaarde van die deelnemers voldoen.

"Dit moet vars wees en dit moenie bleek groente wees nie. En as dit mooi netjies opgesny is - is dit vir my baie aantreklik - teenoor 'n pakkie waar dit nie alles ewe groot is nie. Ek weet dit is finicky-geit, maar as ek dit gekoop het, moet almal presies dieselfde lyk.

Sloan (1998) maak melding van die groeiende tendens ten gunste van vars, natuurlike produkte. Met behulp van moderne verpakkingstegnologie kan die voedselindustrie bederfbare produkte 'n langer rakleeftyd gee (Bennion \& Scheule, 2000:676), wat dus hierdie verbruikersbehoefte ondersteun.

Voorkoms van verpakte produkte 'n Aantreklike verpakking en realistiese produkvoorstelling blyk die aandag te trek van sommige deelnemers. Die totale voorkoms van die winkel skep ook bepaalde verwagtings:

"Almal het die persepsie dat (A) se goed lekkerder gaan wees - lasagne van (A) dink jy - outomaties omdat hy mooier in die boksie lyk, die hele winkel lyk vir jou mooier, is hy klaar in jou kop vir jou lekkerder as ' $n$ (B) ene."

Vir sommige deelnemers skakel ' $n$ volledig bereide nagereg wat presies soos die voorstelling op die verpakking lyk, psigologiese risiko uit, veral wanneer gaste oorgenooi word. Sy hoef haar nie oor die nagereg te bekommer nie en kan dus nie in "n swak lig gestel word nie. Die aantreklike nagereg kan haar moontlik komplimente besorg wat haar ego ' $n$ hupstoot kan gee.

"Lemon meringue is vir my lekker om uit daai boks te haal en dit lyk presies soos op die prentjie, en dit is gesny en 'n flop kan nie nog daar in kom nie."

Kinders wat saam met hul ma's inkopies doen, kan ook die aankoopbesluit van bepaalde produkte rig. Vrolike, kleurvolle verpakkings trek kinders se aandag (Mcllveen et al, 1991) en dan word produkte, soos die koekie- en muffinmengsels, gekoop om dit saam met die kinders voor te berei.

"Omdat hulle dit (kits-koekiemengsels) sou kies in die winkel en dan is die prentjie mos nou klaar voorop so hulle sien dit en dit trek hulle aandag en dan koop ons dit en maak dit.

\section{Gesondheidswaarde}

Gesondheidswaarde is gekodeer in sinne waar woorde soos 'vitamienaanvullings', 'gesond eet', 'gesonde kos', 'voedingswaarde', 'vetinhoud', 'cholesterol' en 'etikette' voorgekom het. Met behulp van spilkodering is die konsepte verbind met aspekte waarmee dit verband hou soos die tipe voedsel wat as gesond beskou word.

'Gesonde kos' is vars produkte Voedingswaarde blyk nie een van die belangrike kriteria te wees waaraan geriefsvoedsel gemeet word nie. Die deelnemers het wel ' $n$ algemene persepsie van wat gesond en ongesond is en dit rig hul voedselkeuses. Vars produkte word aangekoop aangesien die persepsie bestaan dat dit gesonder is en selfs meer nutriënte bevat as gevriesde produkte. Dit stem ooreen met tendense in Amerika waar vars groente en vrugte gekies word vir gesondheidsredes (Sloan, 1999).

"... vars vrugte is daar baie in die huis. So, soos aarbeie en vrugte van die seisoen. So, dit is ek nogal streng op dat dit moet vars wees." 
Verder bestaan die persepsie dat 'gekookte kos' gesond is. Dit is ' $n$ term wat in die volksmond dui op ' $n$ tradisionele hoofmaal bestaande uit ' $n$ vleisgereg, stysel soos aartappel of rys, groente en soms ook ' $n$ slaai. Die groente, soos groenboontjies en pampoen, word op ' $n$ tradisionele wyse gekook. Die begrip 'gekookte kos' sluit by hierdie deelnemers egter ook ander tegnieke van gaarmaak, soos mikrogolfgaarmaak, in.

"Ek hou van gewone kos, gewone kookkos beskou ek as gesonde kos."

Oor die algemeen lyk dit of die deelnemers neutrale persepsies oor die voedingswaarde van geriefsvoedsel het omdat hulle die industrie daarmee vertrou en omdat hulle nie noodwendig weet wat die voedingswaarde van produkte is of behoort te wees nie. Nayga et al (1998) bevestig dat verbruikers algemene voedselnutriënt-assosiasies maak sonder om noodwendig goed ingelig te wees of besondere prioriteit daarop te plaas. Deelnemers met kinders (e, $f$ en $g$ ) wil egter graag die versekering van die industrie hê dat hulle kinders die nodige voedingstowwe inkry:

"Ek glo maar die goed het alles voedingswaarde." "Vitamiene en daai goed - ag nee wat. Ek is nie eintlik vreeslik daarop gesteld nie. Miskien oor ek nie baie kennis daaroor het nie."

Vetinhoud Die mees opvallende persepsies rondom die gesondheidswaarde van (geriefs)voedsel hou verband met die vetinhoud daarvan. Dit lyk asof die versigtigheid vir voedsels met ' $n$ hoë vetinhoud, saamhang met die persepsie dat dit 'n risiko vir die gesondheid en liggaamsgewig inhou. Hill et al (2002) en Sloan (1999) bevestig dat die keuse van laevetprodukte verband hou met ' $n$ besorgheid oor gesondheid en/of liggaamsgewig. Dit gaan dus gepaard met die fisieke risiko dat die gesondheid asook liggaamsmassa daaronder kan lei indien produkte met ' $n$ hoë vetinhoud, voortdurend gekoop en geëet word. Uit 'n gesondheidsoogpunt, is dit ' $n$ verblydende tendens:

“... ek kyk byvoorbeeld na kilojoule inhoud (op die etiket) , maar dit is minder vir my as vet."

"Bloot vir die vetinhoud daarvan, dink ek as mens kyk na cholesterol-vlakke en daai, dink ek nie dit is altyd die gesondste keuse nie." "Hy (deelnemer se man) is baie oorgewig, kom ek stel dit so, hy was baie oorgewig en hy het nou al met hierdie leefstyl (bedoelende laevetprodukte) gewig verloor vandat ons getroud is, sewe maande. En stadig maar seker skud ons albei vet af want ons eet lae vet of geen vet."

Om voedsels te kies waarvan die vetinhoud aanvaarbaar is, word inligting op die etikette bestudeer vir aanduidings van vetinhoud soos onder andere 'laevet produkte' en ' $50 \%$ minder vet' voordat dit aangekoop word. Sommige deelnemers ( $a, d$ en e) het ook baie spesifieke persepsies oor die aanvaarbare hoeveelheid vet:

“... ek kyk daarop (etikette)- daai wat hulle sê vet / 100g. Ek probeer werk so op 4 (g/100g)."

Dit blyk egter dat dieptekennis oor die hoeveelheid vet en veral die tipe vet wat in die dieet ingesluit behoort te word, ontbreek. Die deelnemers het wel al- gemene riglyne ten opsigte van vetinhoud van voedselprodukte wat hulle as toelaatbaar beskou. Die voedselindustrie sou dus kon voortgaan om produkte met beperkte vetinhoud te ontwikkel, maar sou meer aandag kon gee aan maniere om die inligting op ' $n$ maklik verstaanbare manier aan verbruikers te kommunikeer, aangesien verwarrende boodskappe volgens Hill et al (2002) verbruikersvertroue knou.

Voedingswaarde gekoppel aan die geleentheid Hoewel sommige deelnemers ( $b$, $d$ en e) gedurende die week besorgd is oor die vetinhoud van hul dieet, let hulle oor naweke nie veel daarna op nie:

"In die week ... probeer ons om so gesond moontlik te eet, nie daai vetterige en olierige goeters nie. Oor naweke ... miskien room gebruik om sous te maak of chips te maak ..."

Die persepsie bestaan by die genoemde deelnemers dat die insluiting van sekere voedsels met ' $n$ hoë vetinhoud, toelaatbaar is vir spesiale geleenthede, as ' $n$ manier om jouself te bederf en omdat dit lekker is. Volgens Sloan (1999) balanseer Amerikaners hul dieet met 'goeie' en 'slegte' voedsels. 'Slegte' voedsels veronderstel ryk, romerige produkte soos kaaskoek, Tiramisu, koekies en versnaperinge ('snacks') soos skyfies en lekkers. Hill et al (2002) verduidelik dat die smaak en tekstuur van laevetprodukte dikwels nie so aangenaam as dié van hoëvetprodukte is nie en moontlik vandaar die assosiasie dat voedsels met ' $n$ hoë vetinhoud gekoop word om jouself mee te bederf.

\section{Kwaliteit}

Slegs deelnemer $h$ verwys pertinent na die kwaliteit van geriefsvoedsel. Kwaliteit veronderstel ' $n$ uitnemende produk ten opsigte van eienskappe wat reeds bespreek is soos voorkoms, smaak, voedingswaarde en selfs prys. Hierbenewens word kwaliteitspersepsies ook gekoppel aan die produkte van bepaalde winkelgroepe en daarom is verbatim-aanhalings geïdentifiseer en gekodeer vir 'kwaliteit' en 'winkel': “... 'n opset soos (A) s'n waar mens kwaliteit produkte $k r y$, wat ' $n$ stempel van akkreditasie het, dis waarskynlik finansiële limitations wat maak dat ek nie daar koop nie ..."

Hoewel positiewe persepsies van dié spesifieke winkelgroep (A) se kwaliteit pertinent was, het die meeste van die deelnemers nie die betrokke winkelgroep vir roetine-voedselaankope ondersteun nie, aangesien die persepsie bestaan dat die produkte duur is. Vir spesiale geleenthede word daar soms uitsonderings gemaak en dié winkel dien dus as ' $\mathrm{n}$ denkkortpad om die aankoopbesluit te regverdig:

"As ek egter iets spesiaals wil voorberei, dan doen ek die ekstra moeite om by $(\mathrm{A})$ uit te kom."

Kwaliteituitsprake en produkvoorkeure hou verband met produkeienskappe (Kupiec \& Revell, 2001), maar ook met die betrokke winkel. Verskillende mense heg egter verskillende betekenisse aan kwaliteit (Furst et al, 1996). 


\section{Veiligheid}

Voedselveiligheid impliseer die afwesigheid van mikrobiologiese, chemiese of tegnologiese risiko's (Yeung $\&$ Morris, 2001). Die deelnemers is spesifiek gepols oor veiligheidsaspekte rondom geriefsvoedsels, aangesien hulle nie spontaan daaroor gepraat het nie. Een deelnemer stel dit so: “...dit (voedselveiligheid) kom nie eens by my op nie." Oor die algemeen lyk dit of hierdie deelnemers nie juis begaan is oor die veiligheid van die voedsel wat hulle koop nie en dit kan moontlik toegeskryf word aan die feit dat hulle bewus is wat veilige voedsel behels en in elk geval dienooreenkomstig produkte kies en koop. Attwell (2003) skryf hierdie verbruikersgerustheid toe aan die gehalte van die voedselindustrie in Suid-Afrika. Volgens Leach et al (2001) is voedselveiligheid ook nie ter sprake wanneer die publiek ' $n$ restaurant uitkies nie, aangesien hulle keuse eerder deur die kwaliteit van die voedsel bepaal word. Dit was ook duidelik uit hierdie studie.

Enkele deelnemers (c, d en g) het fisieke risikopersepsie rondom die mikrobiologiese veiligheid van geriefsvoedsel ervaar. Die voedselsoorte waaroor besorgdheid bestaan, is hoender, vis, verkoelde slaaie, pasteie en verhitte gereed-om-te-eet-geregte wat in bain maries (warmhou-toestelle) gehou word. Die redes is dat deelnemers nie seker is van die temperatuurbeheer of die tydsduur wat die voedsel staan nie en dit kan as ' $n$ hindernis vir die industrie beskou word, aangesien hierdie produkte vermy sal word.

"Ek sal dit (vis en hoender) nie by 'n ou kafeetjie of by so iets koop nie - jy koop dit by 'n winkel waar die omset groot is." “... veral pasteitjies koop ek glad nie ... dit staan in daai glaskas ... onder die ligte en ' $n$ ou weet nie hoe lank nie, en pasteitjies kan oorstaan ...". "Ek sal byvoorbeeld ook nooit daai ... slaaie koop nie - daai wat in die sirkel uitgepak is nie. ... wonder ek hoe lank staan dit al. Sulke klaar koue goed is vir my partykeer ' $n$ ding wat ek nie sommer sal koop nie en dan daai bakke gaar kos van hulle ... "

Een deelnemer (d) vermy blykbaar mikrobiologiese risiko deur bekende en betroubare verskaffers te ondersteun: "Dis vir my swaar as ons Jefferysbaai toe gaan om dan geriefsvoedsel (gereed-om-te-eetgeregte) daar aan te koop. Jy ken nie daai verskaffer soos jy jou eie verskaffer ken nie en jy weet nie regtig wat jy koop nie. Jy los fisies jou kos in iemand anders se hande en dis " $n$ vertrouensverhouding vir my."

Een deelnemer (c) het haar besorgdheid uitgespreek oor die mikrobiologiese veiligheid van slaaibestanddele, aangesien dit gebruik kan word sonder om dit af te spoel soos wat ' $n$ mens met 'n slaaikop en ander slaaibestanddele sou maak. Slaaibestanddele word nie aan 'n eindkookproses onderwerp wat skadelike mikro-organismes kan vernietig nie. Dit is delikaat en kneus maklik. Derhalwe sal die was- en verpakkingsproses in die industrie hoogs waarskynlik mens-gedrewe wees. Hierdie deelnemer (c) merk tereg op:

“... jy wonder wie berei dit (slaaibestanddele) voor, wie sny dit en jy eet dit net so uit die pakkie uit - ek kook dit nie, dis net so rou - daar wonder ek partykeer."

Om bogenoemde risikopersepsies uit te skakel, sou dit goed wees as kleinhandelaars hul beleid ten opsigte van temperatuurbeheer en hoe gereeld die produkte vervang word, aan verbruikers kommunikeer. Verbruikersopvoeding in terme van hoe volledig voorbereide geregte hanteer moet word nadat dit gekoop is, is ook van uiterste belang. Verbruikers kan nie verwag dat voedsel heeltemal vry van mikro-organismes moet wees nie en daarom sou opvoeding oor die veilige hantering van voedsel tuis, nadat dit gekoop is, sinvol wees (Reid et al, 1998; Leach et al, 2001). Wat bestanddele, soos slaaiblare, slaaimengsels en rou groentes betref wat nie aan 'n eindkookproses onderwerp word nie, sou dit goed wees as die industrie verbruikersvertroue kon inboesem deur aan te dui wat hulle doen om die veiligheid van die produk te verseker. Dit is tans die strewe van die totale voedselproduksieketting om voedselveiligheid vir die verbruiker te verseker en baie maatskappye doen dit deur die internasionale HACCP beginsels na te kom. HACCP is die akroniem vir 'Hazard Analysis at Critical Control Points' (McSwane et al, 2000:63).

\section{SLOT}

Hoewel hierdie studie slegs die persepsies van enkele beroepsvroue op die tafel sit, kan afgelei word dat die genoemde produkeienskappe as sleutelfaktore in die keuse en gebruik van geriefsvoedsel beskou kan word. Figuur 1 stel die eienskappe wat deur die deelnemers geïdentifiseer is, skematies voor en dit dui ook op die onderlinge interaksie tussen die eienskappe. Hoewel voedselveiligheid nie prominent in die geheue-skemata van die deelnemers was nie, word dit wel ingesluit as ' $n$ moontlike aspek wat hul voedselkeuse kan rig, maar verdere navorsing daaroor word aanbeveel.

Verbruikersnavorsing soos hierdie sou 'n belangrike rol kon speel in die voedselindustrie se produkontwikkelings- en bemarkingsbenadering. Verbruikers se persepsies oor die eienskappe van voedselprodukte kan eerstens ' $n$ bydrae lewer om produkte daar te stel wat aan die verwagtings en behoeftes van die teikengroep voldoen. Daar kan voortgebou word op die eienskappe waaroor daar positiewe persepsies bestaan, terwyl die eienskappe waaroor daar negatiewe persepsies, ofte wel risikopersepsie bestaan, verder ontleed kan word sodat die nodige aanpassings gemaak kan word om wel aan die verwagtings van die teikengroep te voldoen. Die bemarkingsboodskap en produk behoort ook die ooglopende voordele waarna die verbruiker soek, uit te lig (Messenger, 2003). Hawkins et al (2001:285) stel dat verbruikers nie passiewe ontvangers van bemarkingsboodskappe is nie, maar dat hulle dié boodskappe 'filtreer' wat hulle sal help om hulle doelwitte te bereik en hulle behoeftes te bevredig. Mens kan dus aflei dat beroepsvroue slegs dié geriefsvoedselprodukte en boodskappe sal waarneem en interpreteer wat vir hulle persoonlik relevant is en 


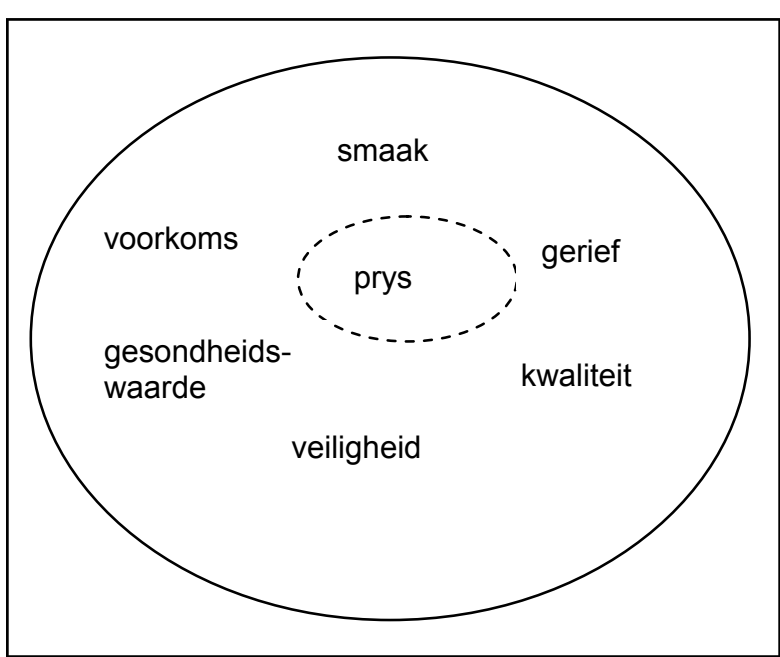

\section{FIGUUR 1 INTERAKSIE TUSSEN DIE EIEN- SKAPPE VAN GERIEFSVOEDSELPRODUKTE}

waarvan daar positiewe persepsies in die geheueskemata bestaan.

Die vraag of geriefsvoedsel as ' $n$ reddingsboei beskou kan word vir die beroepsvroue wat aan hierdie ondersoek deelgeneem het, kan soos volg beantwoord word. Dit lyk of geriefsvoedsel ' $n$ wisselende markaandeel verkry het. Gedeeltelik voorbereide geriefsprodukte en -bestanddele (teenoor volledig voorbereide disse en kitskos) het reeds tot ' $n$ mate inslag gevind. Volledig voorbereide geriefsvoedsel blyk nog beperkte byval te vind by die groter huishoudings vanweë die prys per porsie en/of die onbevredigende smaak. Dit is moontlik omdat die norm van 'tuisbereide' voedsel deel is van die geheueskemata. Geriefsprodukte en -bestanddele bied wel die moontlikheid om disse met die gewone/verwagte smaak te berei. Namate die volgende generasie toenemend geriefsvoedsel gebruik, en ook al minder die kennis en vaardigheid ontwikkel om self ' $n$ maaltyd van meet af voor te berei, sal die smaak van geriefsvoedsel moontlik die norm raak. Gekoopte pizzas, wat ' $n$ relatiewe onlangse gereg op die repertoire van ons voedsels is, is ' $n$ voorbeeld.

Die rol van huiswerkers wat tans nog in sommige huishoudings baie van die sleurwerk van voedselbereiding, veral gedurende die week, verrig, mag ook die algemene gebruik van geriefsvoedsel vertraag (Kok, 2003:103). Tog het dit ook geblyk dat wanneer huiswerkers gedurende naweke nie daar is om hulp te verleen nie, daar meer geredelik van geriefsvoedsel gebruik gemaak word.

\section{LITERATUURVERWYSINGS}

ASP, EH. 1999. Factors affecting food decisions made by individual consumers. Food Policy 24:287294.

ATTWELL, E. 2003. Safe or ignorant? Food Review 30(1):16.
BABBIE, E \& MOUTON, J. 2001. The practice of social research. Oxford. Oxford University Press.

BARON, RA \& BYRNE, R. 1997. Social psychology. $5^{\text {th }}$ Ed. Boston. Allyn and Bacon.

BEHARREL, B \& DENISON, T. 1991. Food choice in a retail environment. British Food Journal 93(7):2430.

BENNION, M \& SCHEULE, B. 2000. Introductory foods. $11^{\text {th }}$ Ed. New Jersey. Prentice-Hall.

BOCK, MA, READ, M, BRUHN, M, AULD, G, GABEL, $\mathrm{K}$, LAURITZEN, G, LEE, Y, MCNULTY, J, MEDEIROS, D, NEWMAN, R, NITZKE, S, ORTIZ, M, SCHUTZ, H \& SHEEHAN, E. 1998. Gender and ethnic differences in factors that influence food intake. Journal of Consumer Studies \& Home Economics 22 (1):25-37.

BOTHA, P. 2001. Die kwalitatiewe onderhoud as data-insamelingstegniek; sterk en swak punte. Tydskrif vir Gesinsekologie en Verbruikerswetenskappe 29:13-19.

BRECH, DM. 1998. The food service industry as a support for employed mothers. Journal of Family and Consumer Sciences (Summer):20-22.

CALLAHAN, JC. 1988. Ethical issues in professional life. New York. Oxford University Press.

CANDEL, MJJM. 2001. Consumers' convenience orientation towards meal preparation: conceptualization and measurement. Appetite 36:1528.

CAPPS, O, TEDFORD, JR \& HAVLICEK, J.1985. Household demand for convenience and nonconvenience foods. American Journal of Agricultural Economics (November):862-869.

CARDELLO, AV. 1996. The role of the human senses in food acceptance. In MEISELMAN, HL \& MACFIE, HJH, 1996. Food choice, acceptance and consumption. London. Blackie Academic \& Professional.

CATTERALL, M \& IBBOTSON, P. 2000. Using projective techniques in education research. British Educational Research Journal 26(2):245-257.

DARIAN, JC \& COHEN, J. 1995. Segmenting by consumer time shortage. Journal of Consumer Marketing 12(1):32-44.

DARIAN, JC \& TUCCI, L. 1992. Convenienceoriented food expenditures of working-wife families: implications for convenience food manufacturers. Journal of Food Products Marketing 1(1):25-36.

DAVIES, DL. 2001. Review of the UK marketplace for convenience foods. Nutrition and Food Science 31 (6):319-335.

DAVIES, G. 1997. Time, food shopping and food preparation: some attitudinal linkages. British Food Journal 99(3):80-88.

DECROP, A. 1999. Triangulation in qualitative tourism research. Tourism Management 20:157-161. DE VOS, AS. 2002a. Combined quantitative and qualitative approach. In DE VOS, AS, STRYDOM, H, FOUCHé, CB \& DELPORT, CSL. Research at grass roots. $2^{\text {nd }} E d$. Pretoria. Van Schaik.

DE VOS, AS. 2002b. Scientific theory and professional research. In DE VOS, AS, STRYDOM, $\mathrm{H}$, FOUCHé, CB \& DELPORT, CSL. Research at grass roots. $2^{\text {nd }} E d$. Pretoria. Van Schaik.

ESHLEMAN, JR. 1974. The family. $7^{\text {th }}$ Ed. Boston. 
Allyn \& Bacon.

FISKE, ST \& TAYLOR, SE. 1991. Social cognition. $2^{\text {nd }}$ Ed. New York. McGraw-Hill.

FURST, T, CONNORS, M, BISOGNI, CA, SOBAL, J \& FALK, LW. 1996. Food choice: A conceptual model of the process. Appetite 26:247-266.

GARBER, LL, HYATT, EM \& STARR, RG. 2003. Measuring consumer response to food products. Food Quality and Preference 14:3-15.

GREEFF, M. 2002. Information collection: interviewing. In DE VOS, AS, STRYDOM, $\mathrm{H}$, FOUCHé, CB \& DELPORT, CSL. 2002. Research at grass roots. $2^{\text {nd }} \mathrm{Ed}$. Pretoria. Van Schaik.

GOFTON, L. 1995. Dollar rich and time poor? British Food Journal 97(10):11-16.

HAWKINS, DI, BEST, RJ \& CONEY, KA. 2001. Consumer behaviour. Boston. McGraw Hill.

HILL, DS, KNOX, B, HAMILTON, J, PARR, H \& STRINGER, M. 2002. Reduced fat foods: the shopper's viewpoint. International Journal of Consumer Studies 26(1):44-57.

HOLLANDER, SL. 1988. Projective techniques uncover real consumer attitudes. Marketing News 22 (1):34.

HORTON, S \& CAMPBELL, C. 1991. Wife's employment, food expenditures, and apparent nutrient intake: evidence from Canada. American Journal of Agricultural Economics (August):784-794.

IMRAM, N. 1999. The role of visual cues in consumer perception and acceptance of a food product. Nutrition and Food Science 99(5):224-230.

JAE, MK, RYE, JS \& ABDEL-GHANY, M. 2000. Family characteristics and convenience food expenditure in urban Korea. Journal of Consumer Studies and Home Economics 24(December):252256.

KAISER, S. 1990. The Social psychology of clothing. $2^{\text {nd }} E d$. New York. Macmillan.

KINSEY, JD. 1997. What's new - what's not? Cereal Foods World 42(11):919-920.

KOK, M. 2003. Bepaalde beroepsvroue se persepsies van geriefsvoedsels in die keuse, aankoop en gebruik daarvan. Ongepubliseerde Magisterverhandeling in Verbruikerswetenskap (Voedselbestuur). Universiteit van Pretoria.

KRONDL, M. 1990. Conceptual models. In ANDERSON, HG. Diet and behaviour. Multidisciplinary Approaches. London. SpringerVerlag.

KRONDL, M \& COLEMAN, MS. 1988. The role of food perceptions in food use. Current Concepts in Nutrition 16:53-78.

KUPIEC, B \& REVELL, B. 2001. Measuring consumer quality judgements. British Food Journal 103(1):7-22.

LAUTMAN, MR. 1982. Focus groups: theory and method. Advances in Consumer Research XIX:52-55. Twelfth Annual Conference. [sl]. Association for Consumer Research.

LAWLESS, HT \& HEYMAN, H. 1998. Sensory evaluation of food. Principles and practices. New York. Chapman \& Hall.

LEACH, J, MERCER, H, STEW, G \& DENYER, S. 2001. Improving food hygiene standards - a customer focused approach. British Food Journal 103
(4):238-252.

LEEDY, PD.\& ORMROD, JE. 2001. Practical research. Planning and design. $7^{\text {th }}$ Ed. Upper Saddle River, New Jersey. Prentice-Hall.

LEVY, M \& WEITZ, BA. 2001. Retailing management. Boston. Mc Graw-Hill Irwin.

MADILL-MARSHALL, JJ, HESLOP, L \& DUXBURY, L.1995. Coping with household stress in the 1990s: Who uses "convenience foods" and do they help? Advances in Consumer Research 22:729-734.

MAINLAND, DD. 1998. Health and the demand for food in Scotland: economic and demographic effects. British Food Journal 100(6):273-277.

MANRIQUE, J \& JENSEN, HH. 1997. Spanish household demand for convenience meat products. Agribusiness 13(6):579-586.

MANRIQUE, J \& JENSEN, HH. 1998. Working women and expenditures on food away-from-home and at-home in Spain. Journal of Agricultural Economics 49(3):321-333.

McILVEEN, H, GRANT, B \& ARMSTRONG, G. 1991. Children: the food marketer's dream. The Home Economist 18(2):21-24.

McSWANE, D, RUE, N \& LINTON, R. 2000. Essentials of food safety and sanitation. $2^{\text {nd }} \mathrm{Ed}$. Upper Saddle River, New Jersey. Prentice-Hall.

MESSENGER, B. 2003. Why do new products fail? Food Review 30(1):35.

MEYER, WF. 1991. Basic concepts of developmental psychology. In LOUW, DA. (Ed.) 1998. Human Development. Pretoria. Kagiso Tertiary.

NAYGA, RM, LIPINSKI, D \& SAVUR, N. 1998. Consumers' use of nutritional labels while food shopping and at home. Journal of Consumer Affairs 32(1):106-115.

NEALL, B. 2003. Unequivocally, taste does matter. Food Review 30(1):8.

NEUMAN, WL. 2000. Social research methods. Qualitative and quantitative approaches. $4^{\text {th }} \mathrm{Ed}$. Boston. Allyn and Bacon.

OAKLEY, A. 1981. Interviewing women: a contradiction in terms. In ROBERTS, H. Doing feminist researches. London. Routledge \& Kegan Paul.

OLSON, JC. 1981. The importance of cognitive processes and existing knowledge structures for understanding food acceptance. In SOLMS J \& HALL, RJ. Criteria of Food Acceptance. Zurich. Forster Verlag AG.

REED, Z, McILVEEN, H \& STRUGNELL, C. 2001. The chilled ready meal market in Northern Ireland. Nutrition and Food Science 31(2):101-111.

REID, A, WOOD, D \& KINNEY, D. 1998. Food hygiene information: power to the people? Nutrition and Food Science 3 (May/June):138-144.

SCHAFFNER, DJ, SCHRODER, WR \& EARLE, MD. 1998. Food marketing. An International Perspective. Malaysia. McGraw-Hill.

SCHIFFMAN, LG \& KANUK, LL. 2000. Consumer behavior. $7^{\text {th }}$ Ed. New York. Prentice Hall.

SIMS, LS. 1981. Further thoughts on research perspectives in nutrition education. Journal of Nutrition Education 13(1):S70-S75.

SLOAN, AE. 1998. Food industry forecast: 
Consumer trends to 2020 and beyond. Food Technology 52(1):37-44.

SLOAN, AE. 1999. Top ten trends to watch and work on for the millennium. Food Technology 53(8):40-60. SOLOMON, MR. 1994. Consumer behaviour. Buying, having and being. Boston. Allyn and Bacon. SOMASUNDARAM, TN. 1993. Consumers' reaction to product failure: Impact of product involvement and knowledge. Advances in Consumer Research 20:215-217.

SPINKS, A \& BOSE, S. 2002. Factors affecting households' seafood purchasing decisions in Auckland, New Zealand: an empirical analysis. International Journal of Consumer Studies 26(1):6270.

STRYDOM, H \& VENTER, L. 2002. Sampling and sampling methods. In DE VOS, AS, STRYDOM, H,
FOUCHé, CB \& DELPORT, CSL. Research at grass roots. $2^{\text {nd }} E d$. Pretoria. Van Schaik.

VICKERS, R. 1999. Could the ice be thawing for frozen ready meals? Food Processing 68(8):17-18.

WARDE, A. 1999. Convenience food: space and timing. British Food Journal 101(7):518-527.

WEINER, B. 2000. Attributional thoughts about consumer behaviour. Journal of Consumer Research 27(3):382-310.

WILL, V, EADIE, D \& MACASKILL, S. 1996. Projective and enabling techniques explored. Qualitative Market Research 14(6):38-43.

YEUNG, RMW \& MORRIS, J. 2001. Food safety risk. British Food Journal 103(3):170-178.

ZIKMUND, WG, \& d'AMICO, M. 2001. Marketing. Creating and keeping customers in an e-commerce world. $7^{\text {th }}$ Ed. Ohio. South-Western College. 